\title{
RESPONSABILIDAD CIVIL POR EL INCUMPLIMIENTO DE OBLIGACIONES MATRIMONIALES Y POR EL EJERCICIO ABUSIVO DEL DIVORCIO UNILATERAL. UN ESTUDIO DE SU ADMISIBILIDAD EN CHILE*
}

\author{
Jimena VALENZUELA DEL VALLE**
}

RESUMEN: Este trabajo tiene por finalidad defender la admisibilidad de la indemnización de perjuicios en el ámbito de las relaciones conyugales. La autora se hace cargo de dos supuestos: el primero se refiere a los dańos que ha sufrido el cónyuge inocente por el incumplimiento grave de obligaciones matrimoniales por parte del otro cónyuge, por el que se ha dado lugar a la separación o al divorcio. El segundo supuesto plantea la admisibilidad de la la indemnización de perjuicios en el caso de una pretensión de divorcio unilateral que constituya un abuso del derecho.

PALABRAS CLAVE: Matrimonio - indemnización de perjuicios - responsabilidad - incumplimiento de obligaciones - abuso del derecho

\section{LIABILITY DUE TO BREACH IN THE MARITAL OBLIGATIONS AND FOR THE ABUSIVE EXERCISING OF THE UNILATERAL DIVORCE. A STUDY OF ITS ADMISSIBILITY IN CHILE}

ABSTRACT: The objective of this article is to uphold the admissibility of damages in the arena of marital relationships. The author deals with two assumptions: the first, referred to those losses suffered by the innocent spouse due to serious breach of marital obligations by the other spouse who caused the separation or divorce. The second assumption considers the admissibility of damages in case there is an expected unilateral divorce that represents an abuse of the law.

KEY WORDS: Marriage - damages - liability - breach of obligations abuse of the law

Fecha de recepción: 14 de octubre de 2011.

Fecha de aceptación: 25 de enero de 2012.

** Abogada de la Universidad de Chile; Profesora de Derecho Civil de la Universidad de los Andes, Profesora del Instituto de Ciencias de la Familia de la Universidad de los Andes. Correo electrónico: jvalenzuela@uandes.cl Agradezco las observaciones y comentarios de la profesora María Sara Rodríguez Pinto. 


\section{INTRODUCCIÓN}

El objetivo de este trabajo es defender la admisibilidad de las acciones de indemnización de perjuicios por dańos causados por la infracción grave de deberes matrimoniales, que causa la separación judicial y el divorcio, y por la pretensión unilateral de divorcio efectuada con abuso del derecho. El estudio no tiene por objeto abordar en su totalidad la cuestión de los dańos en el Derecho de familia. En concreto, se excluyen de este análisis los posibles dańos por el divorcio en sí (no por las causas que dieron lugar al divorcio); los posibles dańos con motivo de relaciones patrimoniales entre los cónyuges (por ejemplo, por mala administración del marido de bienes propios o sociales) o los posibles dańos con motivo de las relaciones paterno-filiales (por ejemplo, por negarse el padre al reconocimiento voluntario de un hijo no matrimonial ${ }^{1}$ ).

\section{1) ESTADO ACTUAL DE LA CUESTIÓN CON ESPECIAL REFERENCIA AL DERECHO CIVIL CHILENO}

Puede afirmarse que las acciones de indemnización de perjuicios entre cónyuges no ha sido una temática de mayor interés entre autores y tratadistas chilenos, sino hasta muy recientemente. Por otra parte, la jurisprudencia chilena ha admitido acciones entre cónyuges por motivo de obligaciones personales derivadas del matrimonio, pero hasta ahora no ha dado lugar a acciones de indemnización de perjuicios por daños causados por un cónyuge a otro, en sus relaciones derivadas del matrimonio. Estas son las dos cuestiones que se desarrollan en la primera parte de este trabajo ( 1.) con el propósito de demostrar que no existen obstáculos dogmáticos para mantener la doctrina de la inadmisibilidad.

\section{1.) DOCTRINA CHILENA Y EXTRANJERA}

El cuerpo normativo que conforma lo que se denomina Derecho de familia chileno tiene varias referencias expresas al régimen del Título XXXV del Libro IV del Código Civil. Entre otras normas, pueden citarse los siguientes artículos ${ }^{2}$ : artículo 98 (no se podrá alegar la promesa de matrimonio ni para pedir que éste se lleve a efecto, ni para demandar indemnización de perjuicios); artículo 130 (serán obligados solidariamente

1 Pizarro Wilson, Carlos (2006), "Responsabilidad civil por no reconocimiento voluntario del hijo de filiación extramatrimonial”, en De Verda y Beamonte, José Ramón, Daños en el Derecho de Familia, Revista Aranzadi de Derecho Patrimonial, Edición Monográfica, Madrid, Thompson-Aranzadi, pp. 101-116.

2 En adelante, todas las referencias a normas de las que no se mencione la fuente son referencias a artículos del Código Civil chileno. 
a la indemnización de todos los perjuicios y costas ocasionados a terceros por la incertidumbre de la paternidad, la mujer que antes del tiempo debido hubiere pasado a otras nupcias, y su nuevo marido); artículo 141 (la actuación fraudulenta de uno de los cónyuges para obtener la declaración de bien familiar lo deja obligado a indemnizar perjuicios); artículo 197 (el ejercicio de una acción de filiación de mala fe o con el propósito de lesionar la honra del demandado obliga a indemnizar los perjuicios que se cause al afectado); artículo 328 (en el caso de dolo para obtener alimentos, serán obligados solidariamente a la restitución y a la indemnización de perjuicios todos los que han participado en el dolo); artículo 533 (la administración descuidada o fraudulenta del tutor o curador, aparte otras sanciones, lo deja obligado a indemnizar perjuicios al pupilo); y artículo 544 (el tutor o curador removido de la guarda queda obligado a indemnizar perjuicios al pupilo). Ninguna de estas normas impide la indemnización de perjuicios entre cónyuges. La Ley 19.947, de 2004, no contiene referencias directas a esta materia. Tampoco la excluye.

Sin embargo, los autores chilenos que tratan temas de responsabilidad civil en general pasan en silencio el problema de la aplicabilidad del artículo 2314 y siguientes del Código Civil chileno al Derecho de Familia $y$, en concreto, nada dicen sobre un supuesto privilegio de inmunidad entre cónyuges ni se refieren al problema específico de la infracción de obligaciones personales derivadas del matrimonio ${ }^{3}$. A juicio de un análisis reciente $^{4}$, estos autores "no son conscientes en absoluto" del problema, aunque, como veremos, este aserto no es del todo correcto si se examinan cuidadosamente los tratados más autorizados.

A partir de la Ley 19.947, de 2004, se comienza a sugerir la admisibilidad de la reparación de dańos en este ámbito. Barrientos y Novales sugerían, en los comienzos de la vigencia de esta ley, que debería reconocerse el derecho a pedir indemnización por el daño moral por hechos ocurridos durante la vida matrimonial o a consecuencia de la ruptura. La cuestión, afirmaban, es si admitir esta reparación como una partida reparatoria de la "compensación económica" al término del matrimonio,

Así, por ejemplo, Alessandri Rodríguez, Arturo (2005), De la responsabilidad extracontractual en el Derecho civil chileno, Editorial Jurídica de Chile, Reimpresión de la primera edición, 559 pp.; Tapia SuÁrez, Orlando (2006), De la responsabilidad civil en general y de la responsabilidad delictual entre contratantes, Santiago, LexisNexis, $3^{a}$ edición, 654 pp.; Corral Talciani, Hernán (2003), Lecciones de responsabilidad civil extracontractual, Editorial Jurídica de Chile, Santiago, 423 pp.; Barros Bourie, Enrique (2007), Tratado de responsabilidad extracontractual, Editorial Jurídica de Chile, Santiago, 1230 pp.; Rodriguez Grez, Pablo (2009), Responsabilidad extracontractual, Santiago, Editorial Jurídica de Chile, Reimpresión de la primera edición, 505 pp.

4 Novales Alquézar, Aránzazu (2008), "Responsabilidades especiales. ¿Debería haber en el Derecho matrimonial mecanismos reparatorios?", en Regimenes especiales de responsabilidad civil, Cuadernos de Análisis Jurídicos. Colección Derecho Privado IV. Santiago, Ediciones Universidad Diego Portales, Escuela de Derecho, pp. 119-150. 
por vía de reglas generales de responsabilidad civil extracontractual o por vía del establecimiento de un régimen especial en sede matrimonial ${ }^{5}$. Más adelante pueden citarse, por ejemplo, estudios como los de Herane ${ }^{6}$, que se pronuncia a favor de la posibilidad de estas reparaciones en el caso de incumplimiento de obligaciones matrimoniales. En el mismo sentido, Larroucau ${ }^{7}$. Por su parte Hernández ${ }^{8}$ se inclina, en general, por la no admisibilidad de las indemnizaciones en las relaciones conyugales en caso de incumplimiento de las obligaciones matrimoniales y por el divorcio en sí mismo, salvo en casos muy graves en que el incumplimiento constituya delito: por ejemplo, violencia intrafamiliar con resultado de lesiones. La obra más reciente en la materia, escrita por un chileno en España? ${ }^{9}$ debe adscribirse a la tendencia de quienes admiten acciones de indemnización de perjuicios entre cónyuges.

En el campo del Derecho comparado, hay juristas que niegan la posibilidad de estas indemnizaciones ${ }^{10}$. Especialmente en Espańa pueden mencionarse posiciones más moderadas, como las de aquellos autores que consideran que la indemnización sería admisible cuando se trate de daños producidos por hechos sumamente graves o reiterados, que constituyan una violación a las obligaciones matrimoniales de una entidad tal que resulta fácilmente apreciable por el juez y que al mismo tiempo lesiona derechos fundamentales de la persona ${ }^{11}$. Por ejemplo, para Rodríguez Guitián 12 es fundamental que esta "lesión de derechos fundamentales" sea causada con dolo o culpa grave. En el extremo opuesto, puede citarse

Barrientos Grandón, Javier y Novales Alquézar, Aránzazu (2004), Nuevo Derecho matrimonial chileno, Santiago, LexisNexis, pp. 409-410. Más adelante, Novales parece inclinarse por el establecimiento de un régimen especial. Novales (2008) 119-150.

Herane Vives, Francisco (2006), "Reparación por incumplimiento de los deberes matrimoniales", en Estudios de Derecho Civil II, LexisNexis, Santiago, pp.181-193.

7 Larroucau García, Matilde (2010), "De la naturaleza y características del Derecho de Familia y del adulterio como fuente generadora de responsabilidad civil”, en Revista Chilena de Derecho de Familia (2) 2010, Legalpublishing, Santiago de Chile, pp. 199-206. Hernández Paulsen, Gabriel (2008), Responsabilidad civil por daños ocasionados en las relaciones de familia, en Colegio de Abogados de Chile, Ciclo de charlas Los martes al colegio (charla dictada martes 4 de noviembre de 2008), Separata publicada por Revista del Abogado, 34 pp.

9 Vargas Aravena, David (2009), Daños civiles en el matrimonio, La Ley - Wolters Kluwer Espańa, Madrid, 428 pp.

Díez-Picazo, Luis y Gullón Antonio (2006), Sistema de Derecho Civil Vol. IV, 10a edición, Tecnos, Madrid, pp. 92 a 94, donde sugiere que las obligaciones matrimoniales no son verdaderamente jurídicas; Borda, Guillermo A. (1973), Tratado de Derecho Civil argentino: Familia, Perrot, Buenos Aires, t.1, No 548 ter; Vidal Taquini, Carlos H. (1991), Matrimonio Civil, Ley 23.515, Buenos Aires, p. 516. cho de Familia: Especial referencia al ámbito de las relaciones paterno-filiales, Aranzadi, Pamploma, p. 89ss.; Novales (2008) 119-150. 
al argentino Sambrizzi ${ }^{13}$, que considera que la indemnización debería otorgarse cualquiera sea el perjuicio causado, ya sea moral o patrimonial, resultante de los hechos ilícitos que llevaron a la separación o al divorcio, como también de los derivados por el divorcio en sí mismo; y a David Vargas Aravena ${ }^{14}$ que postula la completa admisibilidad de daños civiles entre cónyuges. En Argentina, en cambio, el problema de la aplicabilidad del Derecho de Dańos a cuestiones entre cónyuges o entre padres e hijos parece haber tenido un notable desarrollo ${ }^{15}$.

\section{(1.2.) RAZONES EN QUE SE APOYAN LAS POSTURAS CONTRARIAS A LA ADMISIBILIDAD DE ESTAS ACCIONES}

Los principales argumentos por los cuales parece que tradicionalmente se ha negado la admisibilidad de acciones de indemnización de perjuicios entre cónyuges, especialmente por incumplimiento de obligaciones matrimoniales, pueden sintetizarse en lo siguiente. Primero: los deberes y derechos emanados del matrimonio serían de carácter ético-moral, por lo que no procedería indemnizar perjuicios por su incumplimiento. Segundo: el Derecho de familia reservaría al incumplimiento de estos deberes sanciones civiles especiales, incompatibles con la indemnización de perjuicios. Tercero: el Derecho de familia, particularmente el Derecho matrimonial, ya contemplaría sanciones pecuniarias suficientes para el caso de incumplimiento de estos deberes ${ }^{16}$.

A estos argumentos habría que agregar, según reportan los mismos autores ${ }^{17}$, un presunto privilegio de inmunidad que existiría entre cónyuges, el cual habría tenido más fuerza en el ámbito anglosajón que en los códigos latinos, donde esta regla tendría una vigencia implícita. No nos haremos cargo de este privilegio porque en Chile parece no tener ni

13 SAmbrizzi, Eduardo A. (2001), Daños en el Derecho de Familia, La Ley, Buenos Aires, p.145

14 Vargas Aravena (2009)

15 Al efecto, pueden citarse, entre otros muchos, los siguientes trabajos: Méndez Costa, María Josefa (2000), "Separación personal, divorcio y responsabilidad civil. Sus fundamentos" en Alterini et al. (2000) Derecho de Daños. Primera Parte. Buenos Aires, Ediciones La Rocca, pp. 637-664. También Novellino, Norberto J. (2000), "Acerca de la procedencia o no de la indemnización por dańos en el Derecho de familia", pp. 35-71; Aracena, Alicia (2000) "La mujer abandonada por el marido y el dańo moral", pp. 267-302; Boero, Victor L. (2000) "Dańos y perjuicios derivados del divorcio" (2000), pp. 303-335; Novellino, Norberto J. (2000) "La causal de adulterio y los dańos producidos al cónyuge inocente" (2000), pp. 337-378, entre otros estudios compilados en Aracena et al. (2000) Derecho de daños. Daños en el Derecho de Familia. Cuarta Parte (A). Buenos Aires, Ediciones La Rocca, 687p. Más recientemente está la obra de Medina, Graciela (2008), Daños en el Derecho de Familia. Segunda edición actualizada. Santa Fe: Rubilzal Culzoni, 688p.

16 Rodríguez Guitián (2009) 33-128; Vargas Aravena (2009) 97-175; Medina (2008) 4964.

17 Rodríguez Guitián (2009) 33-128; Vargas Aravena (2009) 97-175; Medina (2008) 4964. 
haber tenido vigencia. El artículo 489 del Código Penal absuelve de responsabilidad penal a los cónyuges por hurtos y defraudaciones ${ }^{18}$, pero expresamente indica que quedarán sujetos a la responsabilidad civil que emane de los referidos delitos. "Se advierte aquí, explica Etcheberry"19, que el hecho es antijurídico y culpable (se le sigue llamando delito), subsiste la responsabilidad civil, y se establece [la excusa legal absolutoria] sólo por razones de conveniencia social en mantener la armonía familiar [...].” Pueden citarse estudios de antigua data ${ }^{20}$ que discurren sobre la realidad de pleitos entre marido y mujer por obligaciones emanadas del matrimonio que revelan que no parece que se haya invocado alguna vez este privilegio en tribunales chilenos.

Recientemente, al confirmar una sentencia de primera instancia que rechaza una acción de indemnización de perjuicios por adulterio, una Sala de la Corte de Apelaciones de Santiago recapitula los motivos por los que estas pretensiones deberían denegarse ${ }^{21}: 1^{\circ}$ ) porque el Derecho de familia engendra derechos de contenido ético extrapatrimonial, no avaluables en dinero, no coercibles forzadamente; $2^{\circ}$ ) porque los principios que rigen el Derecho de familia, como el orden público, la limitación de la autonomía de la voluntad y el carácter intuito personae de la mayoría de sus actos impediría pretensiones indemnizatorias entre cónyuges; $3^{\circ}$ ) por el fuerte componente ético, metajurídico, que tienen las obligaciones y derechos de familia; $4^{\circ}$ ) porque el adulterio en que se fundamenta la pretensión del actor no tenía definición legal a la fecha en que ocurrieron los hechos en que se fundamenta la demanda; $5^{\circ}$ ) porque como infracción al deber de fidelidad, el adulterio tiene sanciones civiles definidas en diversos preceptos, entre las que no se encuentra la obligación de reparar los dańos causados al otro cónyuge; $y$, finalmente, $6^{\circ}$ ) porque a pesar de ser una infracción grave al deber de fidelidad el adulterio no se configura como un delito o cuasidelito civil. "El Derecho de familia, agrega el fallo

18 Cabe hacer presente que la Ley 20.480, de 2010, sobre violencia intrafamiliar (estableciendo el delito de femicidio), modificó este artículo para excluir el delito de dańos del ámbito de la excusa legal absolutoria. Ley 20.480, de 2010, artículo $1^{\circ}$, número 7). Cf. Santibáñez Torres, María Elena y Vargas Pinto, Tatiana (2011), "Reflexiones en torno a las modificaciones para sancionar el femicidio y otras reformas relacionadas (Ley $\mathrm{N}^{\circ}$ 20.480)", en Revista Chilena de Derecho, Vol. 38 N$^{\circ} 1$, p. 205

Etcheberry, Alfredo (2005), Derecho Penal. Parte General, Santiago, Editorial Jurídica de Chile, Reimpresión de la tercera edición, Vol. II, p. 12.

Por todos, CAFFARENA DE JiLes, Elena (1947), ¿Debe el marido alimentos a la mujer que vive fuera del hogar conyugal?, Santiago, Ediciones Universidad de Chile; y La misma (1949), "¿Puede usarse la fuerza pública para el cumplimiento de la obligación prevista en el artículo 133 del Código Civil?, en Revista de Derecho y Jurisprudencia t. 46, pp. 82-94.

21 Corte de Apelaciones de Santiago, Rol. 7738-2007 (confirma sentencia que rechaza acción de responsabilidad civil extracontractual del marido contra la mujer y su cómplice por adulterio). Redacción del abogado integrante seńor Ángel Cruchaga Gandarillas. Cita Westlaw Chile: CL/JUR/3249/2009. 
(Considerando Décimonoveno), por su especialidad, contempla sus propias sanciones, no siendo aplicable en consecuencia la responsabilidad civil y por ende no corresponde en un caso como el de autos solicitar ni mucho menos conceder la reparación del daño moral." Recapitulando en una proposición todos los fundamentos esgrimidos anteriormente, la sentencia agrega: "Que, finalmente, el hecho que el adulterio siempre haya tenido una sanción especial establecida por el legislador en consideración a la naturaleza de la institución del matrimonio, piedra fundamental del derecho de familia, no permite considerarlo fuente de responsabilidad extracontractual como lo pretende el demandante, pues las normas que regulan tales materias se refieren a la reparación de daños derivados de obligaciones de carácter patrimonial, motivo por el cual no resulta jurídicamente procedente acoger la presente demanda. (Considerando Vigésimo Primero)"22.

Los motivos que fundamentan la negativa de los tribunales a conocer de estas acciones, tal como se leen en esta sentencia que puede considerarse representativa, caen casi todos si se considera (como haremos a continuación) la verdadera naturaleza de las obligaciones matrimoniales, la configuración de su infracción como delito civil si causa daño, y el desarrollo de la admisibilidad del daño moral en la doctrina y jurisprudencia chilenas $^{23}$. También caen cuando se pondera la admisibilidad que, al menos en doctrina, tienen las indemnizaciones de perjuicios por lesiones de derechos de la personalidad ${ }^{24}$, por las que resulta totalmente aplicable el régimen del Título XXXV del Libro IV del Código Civil chileno a materias no patrimoniales, incluidas las del Derecho de Familia. Debe mencionarse, por último, que la debilidad de los argumentos citados más arriba también se ve afectada por la indiscutida procedencia de estas acciones en casos de violencia intrafamiliar constitutiva de delito, de la Ley 20.066, de $2005^{25}$.

\section{2) ADMISIBILIDAD DE LAS ACCIONES DE INDEMNIZACIÓN DE PERJUI- CIOS POR INCUMPLIMIENTO DE OBLIGACIONES MATRIMONIALES}

La admisibilidad de estas acciones se debería apoyar en los siguientes argumentos. Los deberes y derechos emanados del matrimonio son derechos y obligaciones de pleno valor jurídico, con sanciones jurídicas y no

\footnotetext{
22 Comentario crítico a esta sentencia por LARroucau (2010) 199.

23 Por todos y para todos los efectos debe citarse en este campo Domínguez Hidalgo, Carmen (2000), El daño moral, Santiago, Editorial Jurídica de Chile, 2 vols.

24 Barros Bourie (2004) nn, 372-373.

25 Recientemente modificada por la Ley 20.480, de 2010, sobre femicidio y otras reformas. Esta ley restringe la excusa legal absolutoria entre cónyuges a los hurtos y defraudaciones; reiterando la procedencia de acciones civiles emanadas de estos delitos, y también del delito de dańos, entre los mismos cónyuges. Cf. también Hernández Paulen (2008) 17.
} 
meramente morales. Las sanciones civiles especiales asociadas al incumplimiento grave de obligaciones matrimoniales no excluyen otras sanciones, especialmente la indemnización de dańos y perjuicios. Las reparaciones pecuniarias asociadas a la disolución del matrimonio no excluyen la indemnización de dańos no cubiertos por ellas, especialmente la indemnización del daño moral. A continuación se desarrollan el primer y segundo argumento (2.1. a 2.4.4.). El tercer argumento se explica más adelante (4.).

\section{1.) EL INCUMPLIMIENTO DE DEBERES MATRIMONIALES CONSTITU- YE INFRACCIÓN DE OBLIGACIONES JURÍDICAS}

Los derechos y obligaciones emanados del matrimonio, tal cual están consagrados en los artículos 131, 132, 133, 134 y 136 del Código Civil chileno son verdaderamente jurídicos; y no deberes ético-morales. Es decir, la obligación de guardarse fe (artículos 131, 132), la obligación de socorrerse y ayudarse recíprocamente en todas las circunstancias de la vida (artículos 131, 134), la obligación de guardarse recíproco respeto y protección (artículo 131), la obligación de vivir en el hogar común y cohabitar (artículo 133) y la obligación recíproca de darse auxilios y expensas para la litis (artículo 136) obligan jurídicamente bajo amenaza de sanciones civiles, muchas de ellas coercibles. El carácter jurídico de una obligación no se define por su coercibilidad, pues hay obligaciones verdaderamente jurídicas que no admiten coercibilidad, como las obligaciones naturales (artículo 1470). Una cosa es la obligación o el débito y otra la coacción o responsabilidad.

La doctrina chilena más reputada considera los derechos y deberes conyugales como verdaderas obligaciones de carácter jurídico ${ }^{26}$. Claro Solar explica que siendo el matrimonio un contrato entre un hombre y una mujer "debía engendrar obligaciones civiles perfectas y no solamente deberes morales cuyo cumplimiento quedara entregado a los escrúpulos de la conciencia privada" 27 . Refleja esta misma opinión Somarriva, quien califica como "derechos y obligaciones" a los que emanan entre cónyuges por el hecho del matrimonio ${ }^{28}$. El mismo autor, refiriéndose a las sanciones del adulterio, afirma que aunque los tribunales chilenos a la fecha en

26 Alessandri, Arturo, Somarriva, Manuel y Vodanovic, Antonio (2004), Tratado de las obligaciones. Reimpresión de la segunda edición. Santiago, Editorial Jurídica de Chile, Vol. I, n. 5

27 Claro Solar, Luis (edición facsímil 1983), Explicaciones de Derecho civil chileno y comparado, Santiago, Editorial Jurídica de Chile, t. 2, n. 764. Recientemente, defienden la misma postura Barrientos Grandon, Javier y Novales Alquézar, Aránzazu (2004), Nuevo Derecho matrimonial chileno, Santiago, LexisNexis, 420 pp.

28 Somarriva Undurraga, Manuel (1963), Derecho de familia, Santiago, Ediar Editores Limitada, v. I, n 120. 
que escribe no han tenido ocasión de pronunciarse sobre el particular, bien puede admitirse la indemnización de perjuicios contra el cónyuge culpable, como ocurre en la jurisprudencia francesa, "dada la amplitud de la responsabilidad extracontractual y la aceptación unánime que recibe la procedencia de la indemnización del daño moral" 29 . Esta opinión no podría sostenerse si el autor pensara que la obligación de fidelidad en el matrimonio es solo de orden ético-moral.

\section{2) LAS SANCIONES CIVILES POR INCUMPLIMIENTO DE OBLIGACIO- NES MATRIMONIALES SON COMPATIBLES CON LA INDEMNIZA- CIÓN DE PERJUICIOS POR DAŃOS}

La mayor parte de las obligaciones personales derivadas del matrimonio llevan aparejada una o más sanciones civiles para el caso de incumplimiento. La sanción civil del adulterio es el derecho de la mujer a pedir la separación de bienes (artículo 155); y el derecho del cónyuge inocente para pedir la separación (artículo 26 Ley 19.947, de 2004) o el divorcio (artículo 54). La sanción civil de la infracción al deber de socorro es el derecho de la mujer a pedir la separación de bienes (artículo 155) y la obligación recíproca de darse alimentos (artículo 160). La mujer tiene derecho a pedir la separación de bienes por la infracción de cualquiera de las obligaciones expresadas en los artículos 131 y 134 (artículo 155). Tanto el marido como la mujer pueden pedir el divorcio contra el otro de los cónyuges por "violación grave de los deberes y obligaciones que les impone el matrimonio" (artículo 54 Ley 19.947, de 2004).

La infracción grave de deberes y obligaciones matrimoniales, como de cualquier otra obligación derivada de relaciones personales o patrimoniales, incluido el ámbito del Derecho de Familia ${ }^{30}$, puede constituir

29 Somarriva (1963) n. 122. Con posterioridad el Derecho francés tipificó este ilícito, tal como aparece actualmente en el artículo 266 del Código Civil francés (Ley no 75-617 de 11 de julio de 1975 art. 1 Diario Oficial de 12 de julio de 1975 en vigor el 1 de enero de 1976) (Ley no 2004-439 de 26 de mayo de 2004 art. 17 Diario Oficial de 27 de mayo de 2004 en vigor el 1 de enero de 2005): Sin perjuicio de la aplicación del artículo 270, se podrá conceder una indemnización por daños y perjuicios a uno de los cónyuges para reparar las consecuencias de especial gravedad que sufra por el hecho de la disolución del matrimonio, bien cuando fuera la parte demandada en un divorcio pronunciado por alteración definitiva del vinculo matrimonial y sin que hubiese él mismo interpuesto ninguna demanda de divorcio, o bien cuando el divorcio fuese pronunciado atribuyendo exclusivamente las causas de culpabilidad a su cónyuge. Esta petición solo podrá formularse en el procedimiento de divorcio. NOTA: La Ley 2004-439 de 26 de mayo de 2004 entrará en vigor el 1 de enero de 2005, sin perjuicio de las excepciones previstas en el artículo 33 II. Fuente: www.legifrance.gouv.fr (http://195.83.177.9/code/liste.phtml?lang=esp\&c=41\&r=1655) (visitado el 1 de diciembre de 2011). Malaurie, Philipe y Fulchiron, Hugues (2006), La Famille, Defrénois, Paris, $2^{a}$ edición, nn. 691-694; 729-731.

30 Por ejemplo, la injuria atroz del alimentario (artículo 324) lo priva del derecho de alimentos, que es la sanción civil del hecho. Si es un delito, como el atentado grave contra 
también un delito o cuasidelito civil porque el concepto de delito o cuasidelito civil es mucho más amplio que el de un delito o cuasidelito penal. Cualquier hecho ilícito que cause daño a la persona o propiedad de otro (artículo 1437) y que no esté tipificado como delito penal constituye un delito civil. Mayormente lo es si está penado (por lo que todos los delitos o cuasidelitos penales que causan daño engendran la obligación civil de indemnizar). La infracción de deberes y obligaciones matrimoniales es un hecho ilícito, que tiene sanciones civiles, que puede constituir un delito civil si causa dańos patrimoniales o morales.

Como consecuencia de lo expuesto anteriormente, puede concluirse, por ejemplo, lo siguiente: La infracción a un deber matrimonial, como el de guardarse fe (artículos 131 y 132), no lleva aparejada una pena ${ }^{31}$. Si esta infracción es el adulterio, tipificado en el artículo 132 del Código Civil chileno ${ }^{32}$, es un hecho ilícito, contrario a una obligación exigida por la ley. Si este hecho causa daño, es un delito civil que conforme al artículo 2314 del Código Civil chileno engendra la obligación de indemnizar. La tipicidad del adulterio facilita aún más el juicio de ilicitud de la acción que, si causa daño, engendra obligación de indemnizar. Argumentos semejantes podrían construirse a partir de otras infracciones graves de obligaciones matrimoniales, como el deber de vivir juntos, que se infringe con el abandono.

\section{3.) DERECHO DE FAMILIA E INDEMNIZACIÓN DE PERJUICIOS}

A lo anterior hay que agregar que en el Derecho de familia se contempla la indemnización de perjuicios como sanción a la infracción de diversas obligaciones. Es decir, el Derecho de Familia no es un ámbito incompatible con la obligación de indemnizar perjuicios. Por ejemplo, la infracción del contrato de esponsales da derecho para retener las indemnizaciones que se hubieren pagado (artículo 99). Las acciones de filiación

la vida (autor o cómplice del homicidio frustrado en la persona del alimentante), el honor (alimentado autor del delito de injurias contra el alimentante) o los bienes del alimentante (alimentado autor del delito de incendio de inmuebles de propiedad del alimentante), lleva aparejada una pena. Si ha causado dańo (como es evidente en los ejemplos propuestos), del delito nace también una acción civil para la indemnización de perjuicios. La injuria atroz puede no ser un delito penal. En tal caso constituye puramente un delito civil que confiere al alimentante el derecho a demandar indemnización de perjuicios si ha causado dańo a su persona o propiedad. Ejemplo puesto especialmente por ALESSANDRI (2004) n. 10. chileno sobre delitos de adulterio y amancebamiento.

32 Fue precisamente la Ley 19.335, de 1994, la que tipificó civilmente esta infracción introduciendo el texto que hoy leemos en el artículo 132 del Código Civil chileno. Al efecto, Corral Talciani, Hernán (1996), Bienes familiares y participación en los gananciales. La reforma de la Ley $N^{\circ} 19.335$, de 1994, a las relaciones personales y al régimen económico del matrimonio, Editorial Jurídica de Chile, Santiago, p. 20. 
deducidas "de mala fe o con el propósito de lesionar la honra" engendran la obligación de indemnizar los perjuicios al afectado (artículo 197). Los alimentos obtenidos con dolo engendran la obligación solidaria de restituir y de indemnizar perjuicios (artículo 328). El matrimonio celebrado por la mujer antes del tiempo establecido en el artículo 128 (antes de dar a luz o, no habiendo seńales de embarazo, antes de los 270 días subsiguientes a la disolución del matrimonio o declaración de nulidad) engendra la obligación de indemnizar a todos aquellos a quienes la incertidumbre de paternidad hubiere ocasionado perjuicios (artículo 130). Estas reglas indican que siempre que hay perjuicios, los autores de un hecho ilícito quedan obligados a indemnizarlos los perjuicios, incluso in solidum como manda el artículo 2317 del Código Civil chileno (al que se refiere implícitamente el artículo 130). Esta es la regla general del principio establecido en el artículo 2314 del Código Civil chileno.

Podría pensarse que estos supuestos son excepciones de una regla general contraria implícita. Es decir, que solamente existe obligación de indemnizar perjuicios cuando la ley expresamente apela a ella como sanción de un hecho ilícito. No se advierte dónde podría estar la fuente de esa regla implícita cuando el Derecho chileno concede perjuicios por cualquier hecho ilícito que cause daño a otro (artículos 2314, 2329), sin restringir el principio alterum non laedere (a nadie es permitido dañar a otro ${ }^{33}$ ) a la existencia de tipos legales expresos. El principio tendría incluso rango constitucional implícito en el artículo $1^{\circ}$ (las personas nacen libres e iguales en dignidad y derechos) y en las garantías del artículo 19, números $1^{\circ}$ (integridad física y psíquica de la persona) y $7^{\circ}$ (libertad personal). Por tanto, debe negarse el tópico de la incompatibilidad entre el Derecho de Familia y el régimen de responsabilidad civil extracontractual general previsto en el Código Civil chileno para la reparación de todo daño (artículo 2329).

Se ha postulado la necesidad de un régimen especial de reparación de daños para el Derecho de Familia fundamentado en el derecho a indemnización de perjuicios por lesión de derechos fundamentales ${ }^{34}$. Sin embargo, no se observa la necesidad de construir un régimen especial cuando el fundamento dogmático para la admisibilidad de estas acciones es claro en el Derecho chileno, aunque esto todavía no tenga un reconocimiento judicial ${ }^{35}$.

\footnotetext{
33 D. 1.1 .10 .1 (Ulpiano)

34 Novales (2008) 143-150. En el mismo sentido, al comentar unas sentencias españolas, Romero Coloma, Aurelia María (2008), La indemnización entre cónyuges, ex cónyuges y parejas de hecho, Valencia, Tirant 1 oBanch, pp. 89-100

35 Según reportan estudios recientes, salvo en Francia donde se admiten estas acciones desde hace largo tiempo, en otros países la jurisprudencia va paulatinamente abriendo camino a estas acciones. Vargas Aravena (2009) 35-40
} 


\section{4.) ELEMENTOS QUE CONFIGURARÍAN ESTA RESPONSABILIDAD}

Para comprobar la aplicabilidad del sistema general de responsabilidad civil a los daños causados por incumplimiento de obligaciones matrimoniales realizaremos el ejercicio de verificar en el supuesto planteado cada uno de sus elementos ${ }^{36}$.

\subsection{1.) Capacidad delictual o cuasidelictual}

La capacidad delictual no merece un análisis demasiado exhaustivo puesto que se supone que existe si los cónyuges están o estuvieron válidamente casados. Sin embargo, este elemento podría actuar como elemento de exoneración de responsabilidad si el autor del dańo actuó privado de razón, por lo que se configura en él una situación jurídica de demencia (artículo 2319). Son dementes "los que al tiempo de ejecutar el hecho están privado de la razón por causas patológicas" en sentido amplio ${ }^{37}$. Es decir, el autor puede exonerarse de responsabilidad si por cualquier causa independiente de su voluntad se halla privado de razón (artículo 10 del Código Penal) o actuó por enajenación mental (en el sentido de los ar tículos 458 y siguientes del Código Procesal Penal), excepto que la privación de razón obedezca a causas que le sean imputables, como en el caso del artículo 2318: "El ebrio es responsable del daño causado por su delito o cuasidelito" (principio de la actio libera in causa) ${ }^{38}$.

\subsection{2.) Dolo o culpa}

En nuestro sistema, la fuente de la responsabilidad civil es el dolo o la culpa, por las que el hecho dańoso resulta imputable a otro. El hecho ilícito efectuado con dolo se denomina delito; el cometido con culpa, cuasidelito (artículo 2284). Por dolo deberemos entender, como lo hace el Código Civil, la intención positiva de inferir injuria a la persona o propiedad de otro (artículo 44). Conviene observar que en el contexto de este estudio el dolo se configura también por la injuria o dańo a la persona (que engendra dańo moral) y no solo por dańos al patrimonio. Por otra parte, el dolo supone intencionalidad; por lo que siempre será ilícita una conducta dolosa.

\footnotetext{
36 Este ejercicio lo hacemos considerando la sistematización de elementos formulada por lo más pacífico de la doctrina chilena. Alessandri (2005) n. 80. Sin embargo, se efectúan contrapuntos con los desarrollos de la dogmática, expuestos, por ejemplo, en BARros Bourie (2007), nn. 25-26.

37 Alessandri (2005) n. 86

38 Tapia Suárez (2006), p. 132. Cf. también Barros Bourie (2007), n.38.
} 
El Código Civil también tiene un entendimiento de la culpa, como descuido o negligencia, que admite graduación según sea la naturaleza del contrato. En materia extracontractual no se maneja un concepto diferente. De esta manera, según los artículos 44 y otros (como los artículos 2319 y 2329) podría afirmarse que culpa es la falta de diligencia a que se estaba jurídicamente obligado ${ }^{39}$. En términos más objetivos, es culposa la conducta que contraviene deberes de cuidado a los que el demandado está sujeto ${ }^{40}$.

Cuál es el patrón de conducta abstracto, el estándar, con que se debe comparar la conducta del autor del dańo en concreto. Se afirma ${ }^{41}$ que en el ámbito doméstico las personas de desenvuelven más descuidadamente, más desprolijamente. "Existen situaciones, explica $\mathrm{Barros}^{42}$, en que el estándar de cuidado, en consideración a las circunstancias, tiende a acercarse a la culpa grave o al dolo [porque] el derecho suele tolerar descuidos leves." Así parece ocurrir en el ámbito del cumplimiento de obligaciones matrimoniales o domésticas. Es decir, el demandado sería imputable si su conducta no ha sido ni en lo mínimo coherente con la que generalmente se espera de una persona casada en su círculo social, en su ambiente, o ha perseguido directamente causar un perjuicio al otro. Esto es más o menos lo que propone Hernández ${ }^{43}$, quien sugiere apreciar la culpa lo más en concreto posible, comparando la conducta del autor del daño con la de un cónyuge medio en las circunstancias peculiares en las que realizó la acción u omisión culposa.

De acuerdo a estas ideas puede sugerirse que el dolo es sin lugar a dudas causa de imputabilidad por daños causados en las relaciones de familia. De aquí que sea posible afirmar que si la conducta dañosa es constitutiva de delito o ha sido realizada intencionalmente, procede la indemnización de perjuicios civiles. En el campo de acciones culposas debería determinarse el estándar con que los cónyuges deben conducirse en su vida matrimonial y comparar en concreto la conducta del demandado con ese baremo de conducta. Un indicio de este estándar lo fija la envergadura de la infracción a deberes matrimoniales que se imputa al demandado, que debe ser suficiente para haber causado la separación judicial (artículo 26 Ley 19.947) o el divorcio (artículo 54 Ley 19.947).

39 Alessandri (2005) n. 123. Conviene notar que al aplicar este concepto al ámbito extracontractual, el baremo no se refiere exclusivamente al cumplimiento de obligaciones contractuales, sino a la conducta que se espera de un hombre medio en el cumplimiento de sus obligaciones personales.

40 Barros Bourie (2007), n. 39

41 Por ejemplo, Rodríguez Guitián (2009) 129-148.

42 Barros Bourie (2007) n. 46, c).

43 Por ejemplo, Hernández (2008) 25. 


\subsection{3.) Daño}

El daño es un elemento constitutivo esencial del juicio de responsabilidad. Es decir, el dolo o la culpa engendran la obligación de indemnizar solamente si causan dańo. Por daño entendemos lo que la doctrina más pacífica afirma que lo es: "todo detrimento, perjuicio, menoscabo, dolor, molestia que sufre un individuo en su persona, bienes, libertad, honor, crédito, afectos, creencias, etcétera, la destrucción o disminución, por insignificante que sea, de las ventajas o beneficios patrimoniales o extrapatrimoniales de que goza un individuo" aunque no se trate de la lesión de un derecho subjetivo ${ }^{44}$. Se agregan al daño "la violación de uno o de varios derechos subjetivos que integran la personalidad jurídica de un sujeto" ${ }^{45}$. De manera que debe afirmarse que no toda separación o divorcio imputable a culpa de un cónyuge es causa de responsabilidad civil. Sin embargo, el incumplimiento grave de obligaciones matrimoniales que causa la separación o el divorcio es indemnizable cuando causa un dańo reparable. Conforme al artículo 2329, "todo dańo que pueda imputarse a malicia o negligencia de otra persona debe ser reparado por ésta".

El dańo debe ser cierto; es decir, real, efectivo; aunque su cuantía sea incierta, indeterminada o de difícil apreciación. No deja de ser cierto el daño futuro, aunque sea de difícil apreciación, porque en la indemnización de todo daño se comprende el daño emergente y el lucro cesante (artículo 1556), partida esta última de difícil apreciación que no por ello deja de ser indemnizable ${ }^{46}$. Evidentemente se incluye el daño moral (por ejemplo, el dolor causado por la infidelidad del demandado; la pérdida de la estabilidad emocional y económica que proporcionaba a la víctima el continuar casada) ${ }^{47}$.

Se afirma que el daño indemnizable en el ámbito de relaciones domésticas debe ser de una magnitud superior a las molestias normales de la vida ${ }^{48}$. Ya hemos dicho que la cuestión no está en la envergadura del dańo, sino en su existencia e imputabilidad a malicia o negligencia del otro cónyuge. Por otra parte, se comprende que la víctima no va a deducir una acción de indemnización de perjuicios por dańos ínfimos por una simple cuestión de costo-beneficio. Los costos del pleito serían más onerosos que los beneficios que reportaría del él. Esta simple razón abona la idea de que en todo juicio de responsabilidad civil, la víctima acciona cuando la envergadura del dańo justifica las molestias y costos del juicio.

Alessandri (2005) n. 138

Fueyo Laneri, Fernando (1991), Cumplimiento o incumplimiento de las obligaciones, Santiago, Editorial Jurídica de Chile, p. 23.

Alessandri (2005) 139.

Ejemplos puestos por HeRnÁndeZ (2008) 29.

HeRnÁndeZ (2008) 26.
} 
Conforme a las reglas generales, el dańo debe ser probado en su especie y cuantía. Es decir, debe acreditarse en el juicio por todos los medios de prueba legales la naturaleza patrimonial y/o extrapatrimonial del daño. En concreto, no es suficiente invocar daño moral. El daño moral también debe probarse $\mathrm{f}^{4}$. Todo dańo que pueda imputarse a la malicia o negligencia de otro (artículo 2329) es indemnizable, aunque sea de difícil prueba.

\subsection{4.) Relación de causalidad}

Entre el dolo o la culpa y el daño debe mediar una relación de causalidad. De modo que el daño pueda imputarse a malicia o negligencia en la conducta del autor del hecho ilícito. El demandado no sería responsable civilmente si el daño que sufre la víctima no ha sido causado por su malicia, o la omisión de deberes a los que estaba jurídicamente obligado ${ }^{50}$. Por ejemplo, si el demandante padecía depresiones antes del hecho ilícito y pide la reparación de este solo daño moral. Sí se podría alegar un agravamiento de su condición psiquiátrica por causa de malicia o negligencia del demandado (es decir, desaprensión, abandono en situación de enfermedad); y dańos morales de otra especie ${ }^{51}$. Según el artículo 2330, la apreciación del daño debería quedar sujeta a reducción si la víctima "se expuso a él imprudentemente". Es decir, si la comportamiento de la víctima ha contradicho gravemente también el estándar de conducta establecido, el daño debería reducirse proporcionalmente; incluso, podría llegar a excluir la responsabilidad del autor ${ }^{52}$.

Recapitulando lo dicho hasta ahora es posible afirmar que la admisibilidad de las acciones de indemnización de perjuicios por incumplimiento de obligaciones matrimoniales se apoya en la naturaleza juridica o plenamente civil de estas obligaciones, cuya infracción engendra sanciones que no excluyen la configuración de delitos civiles, por cuya causa la víctima tendría derecho a pedir indemnización de daños y perjuicios.

Antes de volver sobre otros aspectos que completan el objeto de este trabajo (4. y 5.) el estudio desarrolla a continuación los argumentos en los que se apoya la admisibilidad de acciones de indemnización de perjuicios por ejercicio abusivo del divorcio por mero cese de la convivencia (divorcio unilateral o divorcio repudio).

\footnotetext{
49 Al efecto, véase Díez Schwerter (1997) 146-149

50 Alessandri (2005) 151ss.

51 Para un tratamiento completo de la causalidad en la dogmática moderna véase BARros Bourie (2007) 241-296.

52 En concreto, véase BARros Bourie (2007) 289.
} 


\section{3) DAŃOS POR UN EJERCICIO ABUSIVO DE LA ACCIÓN DE DIVORCIO UNILATERAL}

La teoría del abuso del derecho postula que el ejercicio de derechos sería abusivo y, por ende, ilícito, si "los motivos concretos del titular no están conformes al fin o a la función que el derecho subjetivo posee según el ordenamiento que lo establece" 53 . Como es imposible el control exhaustivo de los motivos del sujeto, la teoría ha prosperado como un correctivo extremo al ejercicio excesivo o anormal del derecho; un ejercicio que "atendidas las particulares circunstancias, resulta de tal modo contrario a exigencias mínimas de sociabilidad y de buena fe en las relaciones recíprocas, que debe ser limitado por el derecho objetivo" 54 . Es abusivo el ejercicio de un derecho cuando está impregnado de una inequívoca intención de dañar (abuso de derecho en sentido subjetivo) como también cuando según las circunstancias del caso contradice estándares mínimos de sociabilidad y lealtad (abuso del derecho en sentido objetivo) ${ }^{55}$. El abuso del derecho es siempre un ilícito civil ${ }^{56}$ que engendra la obligación de indemnizar perjuicios.

"Todos los derechos, cualquiera sea su fuente, reales o personales, patrimoniales $o$ de familia, y aun las garantías constitucionales son susceptibles de un ejercicio abusivo" 57 . Como situaciones típicas de abuso del derecho pueden mencionarse, entre otras ${ }^{58}$, los siguientes dos grupos de casos: el ejercicio de un derecho con el solo propósito de causar daño a otra persona y la extrema desproporción entre el interés del titular y el efecto negativo que produce en otra persona el ejercicio del derecho. En el primer grupo de casos podría estar el supuesto tipificado en el artículo 197 , inciso $2^{\circ}$, del Código Civil chileno, conforme al cual se ha resuelto recientemente que deben indemnizar perjuicios los que impugnaron la maternidad del demandante por falso parto con el solo objeto de causarle un dańo, pues del resultado del juicio (desestimado por motivos formales) no se seguía ningún beneficio para el demandante ${ }^{59}$. También podría adscribirse a este grupo de casos el supuesto del artículo 141 (fraude en la afectación de un inmueble como bien familiar) e incluso el artículo 328 (dolo en la obtención de alimentos). La regla que sanciona con la obliga-

\footnotetext{
Barros Bourie (2007) 441.

Barros Bourie (2007) 442.

Barros Bourie (2007) 442.

Alessandri (2005) nn.172, 191.

Alessandri (2005) n. 177 (la cursiva es nuestra).

Barros Bourie (2007) 445-451; Alessandri (2005) 181-190.

Corte Suprema, 24 de noviembre de 2009. "Opazo y otro con Brown y otro" (ha lugar a una acción de indemnización de perjuicios por ejercicio de mala fe de una acción de impugnación de la filiación deducida y perdida en un juicio anterior). Cita Westlaw Chile: CL/JUR/3871/2009.
} 
ción de indemnizar perjuicios, aplicable a estos supuestos, puede extenderse analógicamente al caso del divorcio porque expresa un principio general. El abuso del derecho es siempre un hecho ilícito. El cónyuge que pretende el divorcio de mala fe, con la intención de causar un daño, debe indemnizar a la víctima el daño material y moral que le ha causado por su conducta maliciosa.

Otro grupo de casos es el que resulta de una extrema desproporción entre el interés del titular y el efecto negativo que produce en otra persona el ejercicio del derecho. En el ámbito patrimonial hay varios supuestos que permiten graficar este grupo de casos. Por ejemplo, el que pretende la resolución de un contrato por un incumplimiento irrelevante a la envergadura del contrato ejercita abusivamente el derecho a pedir la resolución que le confiere el artículo 1489 del Código Civil chileno y debería ser obligado a indemnizar los perjuicios que esto cause al deudor. Si el vendedor conoce el vicio que afecta la cosa que vende y no lo revela al comprador, su silencio es abusivo y queda obligado a indemnizar los perjuicios que por esto ha causado al comprador (artículo 1861).

La doctrina extiende también sus efectos al ámbito del Derecho de familia. En este contexto se inscribe la llamada "cláusula de dureza" que algunos ordenamientos ofrecen al cónyuge demandado de divorcio y al juez $^{60}$. Por ancianidad, enfermedad, precariedad económica, dependencia del cónyuge demandado, nińos menores especialmente necesitados, el efecto negativo del divorcio puede ser extremadamente desproporcionado con relación al interés del cónyuge que pretende el divorcio. La cláusula no fue tipificada en nuestra Ley 19.497, de $2004^{61}$, pero la doctrina del abuso del derecho debería ser suficiente para restringir un uso así de abusivo del derecho al divorcio que confiere la ley por el mero cese de la convivencia (artículo 55 Ley 19.947, de 2004). Si efectivamente no opera el abuso del derecho como defensa del demandado ${ }^{62}$, la víctima del dańo

Por ejemplo, el $\uparrow 1568$ del BGB expresa: El matrimonio no debería ser disuelto por divorcio, incluso si ya está roto, si la mantención del matrimonio en el interés de nińos menores de la familia es excepcionalmente necesaria por particulares razones, o si el divorcio por extraordinarias circunstancias sería de una severa dureza para el demandado que lo rechaza, de tal forma que la mantención del matrimonio excepcionalmente parece aconsejable incluso tomando en cuenta los intereses del demandante. (Traducción libre de la autora.)

61 La posibilidad de introducir una cláusula de dureza en la ley de divorcio se discutió en el Congreso, pero fue definitivamente rechazada por mayoría parlamentaria. Véase: Historia de la Ley $N^{\circ}$ 19.947: Establece la nueva Ley de Matrimonio Civil, Diario Oficial 17 de mayo de 2004, elaborado por la Biblioteca del Congreso Nacional y accesible en el sitio web de dicha Biblioteca. En: http:/www.bcn.cl/histley/periodos?p=2004 pp. 894, 993, 994, 1020 y 2069 (visitado el 11 de enero de 2011).

62 Romero Seguel, Alejandro (2005), "El contenido del derecho de defensa frente a una acción de divorcio”, en Assimakópulos Figueroa, A. y Corral Talciani, H., Matrimonio civil y divorcio. Análisis crítico y criterios para la aplicación de la Ley 19.947, de 2004, Cuadernos de extensión jurídica (Universidad de los Andes) $\mathrm{N}^{\circ} 11$, pp. 163-180. Véase 
quedaría legitimada para demandar la indemnización de los dańos patrimoniales y morales que le ha causado el ejercicio abusivo del divorcio en sede civil.

Otro argumento que abona la idea de un ejercicio restringido y dentro de límites socialmente aceptables del divorcio es la subsistencia en nuestro ordenamiento de una idea de matrimonio para toda la vida, tal como quedó en el artículo 102 del Código Civil, cuya derogación expresamente se descartó en la discusión de la ley que introdujo el divorcio. Esta idea sustenta la preferencia que debería tener el juez por la perdurabilidad del matrimonio, si por unos mismos hechos y en un mismo proceso un cónyuge demanda la separación judicial y el otro demanda el divorcio $^{63}$. La idea de matrimonio para toda la vida también debería refrenar el ejercicio abusivo del divorcio por cese de la convivencia, cuando el que pretende el divorcio fue el que abandonó el hogar y el demandado se opone a él.

Nuestra legislación no tipifica como un hecho ilícito el ejercicio abusivo del divorcio unilateral. Sin embargo, por vía de principios generales deberían aceptarse las acciones que se funden en un ejercicio abusivo de esta prerrogativa legal porque el principio alterum non laedere impide el ejercicio abusivo de cualquier derecho. Consideramos que es abusivo el divorcio que se pide arbitraria, caprichosa y frívolamente, causando graves perjuicios morales y patrimoniales al cónyuge demandado que se opone a él sin resultados judiciales favorables en sede de familia.

\section{COMPATIBILIDAD DE LA INDEMNIZACIÓN DE PERJUICIOS CON LA COMPENSACIÓN ECONÓMICA}

En lo que queda de este trabajo nos ocuparemos de si es compatible la indemnización de perjuicios a la que nos hemos referido anteriormente en este trabajo con la compensación económica que contempla la nueva Ley de matrimonio civil (Ley $\mathrm{N}^{\circ} 19.497$ de 2004). La proposición que queremos demostrar es que la "compensación económica" es compatible con el derecho de la víctima de daños no reparados por esa vía, especialmente el dańo moral, para pedir que se condene al autor a indemnizarlos. Las razones en que se apoya esta proposición son dos: $1^{\circ}$ ) la "compensación económica” no tiene la naturaleza de una indemnización de daños y perjuicios; y $2^{\circ}$ ) aunque la tuviera, de ninguna manera cubre el daño

también: Corral Talciani, Hernán (2011), Separación, nulidad y divorcio. Análisis desde los principios y las reglas de la Ley de Matrimonio Civil, Santiago: AbeledoPerrot, $211 \mathrm{p}$. 
moral que la víctima pruebe haber sufrido por causa de la infracción de obligaciones matrimoniales que dieron lugar a la separación o divorcio, o por el ejercicio abusivo del divorcio por mero cese de la convivencia, hechos ilícitos imputables al otro cónyuge por cuyos daños está obligado a responder.

\section{1.) Naturaleza juRídica de la “COMPENSACión eCONÓMica” DE LOS ARTÍ́CULOS 61 A 66 DE LA LEY 19.947}

La mayoría de los autores nacionales opina que la compensación económica prevista en la Ley 19.947 es algo difuso entre beneficio alimenticio o asistencial para el cónyuge más débil, compensación del lucro cesante, o restitución por un enriquecimiento injusto. A continuación examinaré algunas de las opiniones más extendidas para demostrar su compatibilidad con la obligación de indemnizar los daños causados en los dos supuestos que propone este trabajo.

\subsection{1.) La compensación económica como rechazo al enriquecimien- to $\sin$ causa}

Se afirma que se podría encontrar la justificación de la compensación económica en el enriquecimiento sin causa ${ }^{64}$. La mayoría de las mujeres casadas chilenas se dedican preferentemente a las labores domésticas y a la crianza y cuidado de los hijos, labores que muchas veces son incompatibles con actividades remuneradas fuera del hogar, ya sea totalmente o en menor medida de lo que la mujer podría o querría. Esto produciría el enriquecimiento de un cónyuge a costa del otro por lo que el cónyuge beneficiado estaría obligado a realizar un pago al cónyuge perjudicado a fin de equilibrar ambos patrimonios.

No todos los autores coinciden con este planteamiento. Por ejemplo, López Díaz ${ }^{65}$, entre otros argumentos, piensa que para considerar que la compensación económica se justifica en la teoría del enriquecimiento sin causa tendría que darse el elemento esencial de esta institución que es la falta de causa que haga legítima la ganancia de una parte y la pérdida de la otra. El matrimonio y el bien de la familia; y los sacrificios y renuncias que se hacen en su beneficio no podrían considerarse como ausencia de causa, como sí lo son el engańo, el azar, el error u otras malas artes, que son las que verdaderamente se pretenden evitar con el enriquecimiento sin causa.

64 Venegas Ortiz, Pablo Omar y Venegas Alfaro, Andrés Alfonso (2007), La compensación económica en la nueva Ley de Matrimonio Civil, Editorial Jurídica de Chile, Santiago, p.19.

65 López Díaz, Carlos (2006), Compensación económica en la nulidad y el divorcio, Librotecnia, Santiago, p. 76. 


\subsection{2.) La compensación económica como indemnización de perjui- cios}

Para otros, la compensación económica contiene elementos que podrían hacernos concluir que lo que se pretende conceder al cónyuge más débil es una indemnización del lucro cesante; esto es, aquella ganancia económica que podría haber obtenido uno de los cónyuges si hubiera desempeñado un trabajo remunerado fuera del ámbito doméstico y que sacrificó en aras del cuidado y del bien de la familia común. Elección, que en definitiva, redundó en un menoscabo económico que le hace tener expectativas inciertas de seguridad económica para el futuro.

Hay autores ${ }^{66}$ que no concuerdan con esta opinión, ya que la compensación económica, dadas sus características, no correspondería a una genuina indemnización de perjuicios, al no exigir culpa del cónyuge deudor para hacerla procedente. Es decir, en la compensación económica faltaría la conducta ilícita imputable al deudor, elemento esencial de la responsabilidad civil. Tampoco concurre el daño. El menoscabo económico que sufre el cónyuge que se dedicó al cuidado de la familia se produjo por las circunstancias en que se desenvolvió su vida matrimonial y no por una imputación causal a la conducta antijurídica del otro cónyuge.

\subsection{3.) La compensación económica como deber de proporcionar alimentos}

También es cierto que la compensación económica contiene elementos que podrían asemejarla con el derecho de alimentos. En efecto, la ley seńala que si el cónyuge deudor carece de bienes suficientes para pagar la compensación, el juez puede dividirla en cuantas cuotas sea necesario (artículo 66, inciso $2^{\circ}$ de la Ley 19.947); también que al fijarla deba considerarse la capacidad económica del cónyuge deudor (artículo 66 Ley 19.947) y la situación económica del cónyuge beneficiario (artículo 62 Ley 19.947), ambos elementos esenciales en sede de derecho de alimentos.

A pesar de lo dicho también existen poderosos motivos que nos llevan a concluir que la obligación de pagar una compensación económica no es una obligación de alimentos ${ }^{67}$. Por un lado, si nos remitimos a la historia fidedigna de la ley, podemos constatar que los legisladores expresamente señalaron que no se trataría de alimentos. Así el senador Chadwick declaró "que en su opinión, no se trata de alimentos, los cuales

\footnotetext{
66 Pizarro Wilson, Carlos y Vidal Olivares, Álvaro (2010), La compensación económica por divorcio o nulidad matrimonial, Legal Publishing, 3a ed., Santiago, p. 28; Barrientos y NoVALES (2004) 420. 
tienen como objetivo permitir la subsistencia. En cambio, esta institución pretende compensar una expectativa económica a la cual se habría renunciado para dedicarse exclusiva o preferentemente a la familia común". Su opinión coincide con la del senador Espina ${ }^{68}$.

Por otra parte, el término del matrimonio que se produce por el divorcio o la nulidad y que da derecho a la compensación económica, hace cesar el deber de socorro entre los cónyuges que justifica los alimentos entre ellos. Razón que constituye un argumento más para concluir que la compensación económica no es deber de alimentos, excepto en lo referente a su cumplimiento en ciertos casos, como son el modo del pago (en cuotas periódicas), o los apremios que la ley permite para obtener su pago efectivo.

Por último, podemos seńalar como otro argumento para diferenciar ambas instituciones es que el deber de alimentos es esencialmente revisable, esto es que puede ser modificado el monto al cual asciende dependiendo de las circunstancias económicas tanto del deudor como del beneficiario, a diferencia de la compensación económica, que por expresa disposición de la ley, sólo puede ser fijada una sola vez y para siempre.

\subsection{4.) La "compensación económica” como institución sui generis}

La generalidad de los autores coinciden en que la institución de la compensación económica es una suerte de "híbrido", inclasificable en cuanto a su naturaleza jurídica, ya que contiene características de prestación indemnizatoria y a la vez asistencial-alimenticia. Carmen Domínguez $^{69}$ la considera una prestación resarcitoria, aunque reconoce que no reúne todas las condiciones para considerarla como tal y que existen argumentos atendibles que podrían hacer pensar que se trata de un instituto con naturaleza propia y única. Pizarro y $\mathrm{Vidal}^{70}$, anteriormente citados, la consideran una obligación impuesta por la ley a uno de los cónyuges que tiene por objeto corregir el menoscabo económico que como efecto inmediato produce el divorcio o la nulidad. El título que justifica la obligación es la propia ley.

Como restitución por enriquecimiento sin causa, como indemnización del lucro cesante, como prestación alimenticia, o como institución sui generis, la compensación económica es algo distinto a la obligación de

Informe de la Comisión de Constitución, Legislación, Justicia y Reglamento, en Boletín No1.759-18, pp.198 y 199.

69 Domínguez Hidalgo, Carmen (2005), "El Convenio Regulador y la Compensación Económica: Una Visión de Conjunto", en Matrimonio civil y divorcio, Análisis critico y criterios para la aplicación de la Ley No 19.947, de 2004, Cuadernos de Extensión Jurídica No11, Universidad de los Andes, Facultad de Derecho, p.105.

Pizarro (2010) 34. 
indemnizar daños causados por el incumplimiento grave de obligaciones matrimoniales o por el divorcio unilateral ejercitado con abuso del derecho, especialmente cuando se pretende la indemnización del daño moral.

\section{2.) COMPATIBILIDAD ENTRE LA COMPENSACIÓN ECONÓMICA Y LA OBLIGACIÓN DE INDEMNIZAR DAŃOS ENTRE CÓNYUGES}

La "compensación económica" es, por tanto, compatible con la obligación de resarcir los daños que se producen entre cónyuges, ya sea por incumplimiento de las obligaciones conyugales o por el ejercicio abusivo de la acción de divorcio unilateral.

A esto hay que agregar que es posible que el cónyuge inocente en un divorcio por causas imputables al otro, o el afectado por el divorcio unilateral injusto, no tenga derecho a la "compensación económica", ya que su condición no reúne los requisitos exigidos por la ley para dicho beneficio (artículos 61 y 62 de la Ley 19.947, de 2004). Puede ser el caso del cónyuge que durante el matrimonio realizó una labor remunerada fuera del hogar; o el que no está en una situación económica desventajosa con respecto al otro cónyuge.

También es posible la hipótesis que el beneficiario de una "compensación económica" pueda ser demandado de indemnización de daños y perjuicios por el divorcio unilateral que él provocó en forma abusiva. En esta situación se daría la figura de que uno de los cónyuges tiene derecho a la compensación económica y el otro a indemnización por daños y perjuicios. Líquidas y actualmente exigibles, entre ambas obligaciones podría operar una compensación, como modo de extinguir las obligaciones hasta el monto de la de menor valor (artículo 1655 del Código Civil). Esta hipótesis no tendría lugar en el caso de separación o divorcio por culpa, ya que el cónyuge culpable no tendría derecho a compensación económica (artículo 62, inciso 20 Ley 19.947, de 2004).

$\mathrm{La}$ indemnización de perjuicios es, por tanto, compatible con la "compensación económica" prevista en los artículos 61 a 66 de la Ley 19.497, de 2004.

\section{AlgunOS ASPECTOS DEL JUICIO DE RESPONSABILIDAD CIVIL}

Dedicaré la última parte de este trabajo a analizar cuestiones relativas a la acción y al juicio de indemnización de perjuicios entre cónyuges.

\section{1.) COMPETENCIA Y PROCEDIMIENTO}

El tribunal competente para conocer de las causas de indemnización de perjuicios entre cónyuges, actualmente, es el juez de letras en lo civil 
de mayor cuantía del domicilio del demandado (artículo 134 del Código Orgánico de Tribunales).

Antes de la reforma de la Ley 20.286, de 2008, que modificó el artículo $8^{\circ}$ de la Ley 19.968 sobre Tribunales de Familia, la cuestión de la competencia de estos tribunales para conocer de pretensiones indemnizatorias entre cónyuges llegó a discutirse. La Corte de Apelaciones de Concepción, en un emblemático fallo de 25 de octubre de 2007, declaró que era el tribunal de familia el competente para conocer de la demanda de indemnización por daño moral deducida por el marido en un juicio de divorcio por infidelidad de la mujer ${ }^{71}$. La ventaja de concentrar toda la discusión en un solo proceso es evidente por razones de efectiva protección de los derechos de la víctima y por motivos de economía procesal.

Sin embargo, actualmente la cuestión no admite dudas. Desde que el numeral 17 del actual artículo $8^{\circ}$ de la Ley 19.968 atribuye competencia al juez de familia para conocer de "toda otra materia que la ley les encomiende", eliminándose el antiguo numeral 19 del mismo artículo $8^{\circ}$ que atribuía competencia al juez de familia para conocer de "toda otra cuestión personal derivada de las relaciones de familia", la competencia para conocer de las acciones de indemnización de perjuicios entre cónyuges queda entregada al juez de letras en lo civil del domicilio del demandado, conforme a las reglas generales de aplicación supletoria.

El juez de letras competente deberá conocer mediante un proceso de lato conocimiento, esto es juicio ordinario de mayor cuantía (artículo 3 del Código de Procedimiento Civil). Por tanto, para hacer valer su derecho a la indemnización de perjuicios, la víctima, posiblemente demandada en un tribunal de familia, deberá incoar otro proceso en otro tribunal,

71 "2) Que de acuerdo con el artículo $1^{\circ}$ de la Ley $N^{\circ} 19.968$ los juzgados de familia tienen por misión conocer de los asuntos de que trata esta ley y los que les encomienden otras leyes generales y especiales, de juzgarlos y de hacer ejecutar lo juzgado; las materias de su competencia están establecidas en el artículo $8^{\circ}$ en 19 números, el último de los cuales prescribe que debe conocer de: 'Toda cuestión personal derivada de las relaciones de familia'; 3) Que dentro del concepto de relaciones de familia se comprenden indudablemente los derechos y deberes reciprocos que el matrimonio impone a los cónyuges, que se regulan fundamentalmente en los articulos 131 y siguientes del Código Civil, como son el deber de fidelidad, de socorro, de ayuda mutua o asistencia, de respeto y protección reciprocos, derecho y deber de vivir en el hogar común, de cohabitación, de auxilio y de expensas para la litis. 4) Que, por consiguiente, si tales son las relaciones de familia de orden personal que el matrimonio genera en los cónyuges, forzoso es concluir que una deman$d a$, aunque sea de indemnización de perjuicios, que se funde en la infracción de alguno de los deberes antes señalados, es de competencia del Juzgado de Familia". Corte de Concepción, 25 de octubre de 2007, Duhalde con Cuevas, Rol 909-2007 (revoca sentencia del tribunal de familia que acoge excepción de incompetencia para conocer de la demanda reconvencional por la que se pide dańo moral). $N^{\circ}$ Legalpublishing: 37541. Con posterioridad, la Corte de Concepción volvió a pronunciarse en igual sentido. Corte de Concepción, 15 de septiembre de 2008, en Peñaloza con Hebles, Rol 1310-2008 (revoca resolución del tribunal de familia que acoge excepción de incompetencia). $\mathrm{N}^{\circ}$ Legalpublishing: 39891. Estos fallos son buena prueba de la tendencia a pedir indemnización de estos dańos en Chile. 
con la carga y costos de defender sus derechos mediante dos procesos en dos tribunales distintos.

\section{2.) PRESCRIPCIÓN DE LA ACCIÓN}

De conformidad al artículo 2332 del Código Civil chileno, las acciones para pedir indemnización de perjuicios "por daño o dolo prescriben en cuatro ańos contados desde la perpetración del acto". Este plazo de prescripción rige tanto para la responsabilidad delictual o cuasidelictual civil como para la acción civil emanada de un delito.

En la materia de este trabajo surge la dificultad de definir desde cuándo se computa el plazo. En el caso de la responsabilidad por infracción grave de deberes matrimoniales que han sido causa de la separación o divorcio, el plazo podría computarse desde el último de los hechos que causa la separación o divorcio; o desde que queda firme la sentencia que decreta la separación o divorcio. La infracción grave que causa la separación o divorcio puede llegar a ser conocida con posterioridad por la víctima; y el daño generarse también con posterioridad. La víctima se ha visto obligada a deducir acciones judiciales, de resultado incierto, costosas, que pueden agravar las consecuencias dañosas del hecho. La sentencia firme de separación o divorcio da certeza sobre la sanción civil de la infracción invocada y de sus consecuencias (por ejemplo, la procedencia o no, y las partidas aceptadas en una posible "compensación económica"). Si la víctima estima que hay dańos todavía no reparados, especialmente los dańos morales, deberá deducir acción en otro tribunal bajo otro procedimiento. De manera que el plazo debería computarse desde que se completa el hecho dańoso con la producción global del daño ${ }^{72}$, algo que solo ocurre con la sentencia firme. Por tanto, el plazo de cuatro ańos debería computarse desde esta última fecha.

En el caso de la acción por dańos causados por el ejercicio abusivo del divorcio por mero cese de la convivencia, todo indica que el plazo debería computarse desde que queda firme la sentencia que accede al divorcio por esta causa. Solo en ese momento se consuma el abuso que configura el ilícito que da derecho a pedir la indemnización. Antes de ese momento, el cónyuge demandado, víctima del daño, ha podido oponerse a la demanda y hacer valer en juicio todas las defensas que le franquea el Derecho.

Conforme al artículo 2524 del Código Civil, por tratarse de un plazo de prescripción especial de corto tiempo, la opinión general es que no procedería la suspensión del plazo $^{73}$. Sin embargo, el correcto razona-

Corral (2003) 350.

Alessandri (2004) n. 435. 
miento que hace la Corte de Apelaciones de Santiago en un fallo citado favorablemente ${ }^{74}$ debería conducir a la conclusión contraria. "En nuestro Código Civil la expresión 'actos o contratos' se refiere normalmente a los hechos jurídicos voluntarios realizados con la intención de producir efectos jurídicos o a los acuerdos de voluntades destinados al mismo objeto. (Considerando $2^{\circ}$ )" El artículo 2524 se refiere a "las acciones especiales que nacen de ciertos actos o contratos" y no debería comprender, por tanto, a hechos ilícitos, como los delitos y cuasidelitos, pues para incluirlos debería haberlo hecho el legislador en forma expresa. No siendo así, no puede considerarse la prescripción establecida en el artículo 2332 entre las de corto tiempo, a que se refiere el artículo 2524. En consecuencia, la prescripción del artículo 2332 se rige por las reglas de la prescripción ordinaria y le es aplicable el artículo 2509 . El plazo de cuatro años para deducir la acción de indemnización de perjuicios de conformidad al Título XXXV del Libro IV del Código Civil chileno se suspendería mientras los cónyuges se encuentran casados, según el artículo 2509, inciso final. Este argumento ratifica lo dicho más arriba en cuanto al cómputo del plazo.

\section{CONCLUSIONES}

Las acciones de indemnización de perjuicios del Título XXXV del Libro IV del Código Civil chileno deberían servir también para reparar los dańos causados por el incumplimiento de obligaciones matrimoniales que han hecho posible la separación y el divorcio, frustrando el proyecto de vida de la víctima en aspectos que las compensaciones económicas previstas en los artículos 61 y 62 de la Ley 19.947, de 2004 no podrían cubrir. Es especialmente indemnizable por este conducto el daño moral, del todo ausente en las "compensaciones económicas" por nulidad, separación o divorcio previstas en la Ley 19.947, de 2004. Los argumentos que esgrime alguna jurisprudencia chilena reciente para rechazar estas pretensiones, especialmente la naturaleza ético-moral de estas obligaciones y la especialidad del Derecho de Familia, no son admisibles. Las obligaciones matrimoniales serían obligaciones morales si solo tuvieran sanciones también morales; y no es así. Tienen sanciones civiles especiales y no están exentas de la sanción civil residual por antonomasia que es la obligación de indemnizar los daños y perjuicios causados por su infracción.

74 Corral (2003) 351; Corte de Apelaciones de Santiago, 12 de enero de 1988, en Pavez con Vivanco (revoca la sentencia apelada declarando haber estado suspendido el plazo de prescripción a favor del demandante durante su menor edad, por lo que ha lugar a la demanda por la que pide indemnización del dańo moral por el accidente que causó la muerte de su padre). Cita: MJCH_MJJ3758 | RDJ3758. 
La indemnización de perjuicios también debería ser admisible por un ejercicio abusivo del derecho a pedir el divorcio por mero cese de la convivencia (divorcio unilateral o divorcio-repudio). Es abusivo el ejercicio de esta prerrogativa cuando excede los límites sociales que se consideran aceptables y cuando hay una grave desproporción entre la utilidad del titular y los perjuicios del sujeto pasivo.

En el ámbito procesal, estas acciones deben deducirse en sede civil, incoando un proceso de lato conocimiento. El demandante debe producir prueba de la especie y cuantía del dańo; y de los demás elementos que configuran la responsabilidad del demandado.

\section{BIBLIOGRAFÍA CITADA}

- Alessandri Rodríguez, Arturo (2005). De la responsabilidad extracontractual en el Derecho civil chileno. Santiago: Editorial Jurídica de Chile, 559 pp.

- Alessandri, Arturo; Somarriva, Manuel y Vodanovic, Antonio (2004). Tratado de las obligaciones. Reimpresión de la segunda edición. Santiago, Editorial Jurídica de Chile, Vol. I, n. 5.

- Aracena, Alicia (2000). "La mujer abandonada por el marido y el dańo moral", pp. 267-302; en Aracena et al. (2000) Derecho de daños. Daños en el Derecho de Familia. Cuarta Parte (A). Buenos Aires: Ediciones La Rocca, 687 pp.

- Barrientos Grandon, Javier y Novales Alquézar, Aránzauz (2004). Nuevo Derecho matrimonial chileno. Santiago: LexisNexis, 420p.

- Barros Bourie, Enrique (2007). Tratado de responsabilidad extracontractual. Santiago: Editorial Jurídica de Chile, Santiago, $1230 \mathrm{pp}$.

- Boero, Víctor L. (2000). "Daños y perjuicios derivados del divorcio" (2000), pp. 303-335; en Aracena et al. (2000) Derecho de daños. Daños en el Derecho de Familia. Cuarta Parte (A). Buenos Aires: Ediciones La Rocca, 687 pp.

- Borda, Guillermo A. (1973). Tratado de Derecho Civil argentino: Familia. Buenos Aires: Perrot, t. 1

- Caffarena De Jiles, Elena (1947). ¿Debe el marido alimentos a la mujer que vive fuera del hogar conyugal? Santiago: Ediciones Universidad de Chile.

- Caffarena de Jiles, Elena (1949). “¿Puede usarse la fuerza pública para el cumplimiento de la obligación prevista en el artículo 133 del Código Civil?, en Revista de Derecho y Jurisprudencia t. 46, pp. 8294. 
- Claro Solar, Luis (edición facsímil 1983). Explicaciones de Derecho civil chileno y comparado. Santiago: Editorial Jurídica de Chile, t. 2

- Corral Talciani, Hernán (1996). Bienes familiares y participación en los gananciales. La reforma de la Ley $N^{\circ} 19.335$, de 1994, a las relaciones personales y al régimen económico del matrimonio. Santiago: Editorial Jurídica de Chile, p. 20.

- Corral Talciani, Hernán (2003). Lecciones de responsabilidad civil extracontractual. Santiago: Editorial Jurídica de Chile, 423 pp.

- Corral Talciani, Hernán (2006). "El principio de matrimonialidad y las acciones concurrentes de nulidad, divorcio y separación en los procesos de familia”, en Estudios de Derecho Civil II. Santiago: LexisNexis, pp. 151-160, 154.

- Corral Talciani, Hernán (2011). Separación, nulidad y divorcio. Análisis desde los principios y las reglas de la Ley de Matrimonio Civil, Santiago, Abeledo Perrot, 211 pp.

- Díez Schwerter, José Luis (1997). El daño extracontractual. Jurisprudencia y doctrina, Santiago, Editorial Jurídica de Chile, 300 pp.

- Díez-Picazo, Luis y Gullón Antonio (2006). Sistema de Derecho Civil Vol. IV, 10 edición, Tecnos, Madrid.

- Domínguez Hidalgo, Carmen (2000). El daño moral. Santiago: Editorial Jurídica de Chile, 2 vols.

- Domínguez Hidalgo, Carmen (2005). "El Convenio Regulador y la Compensación Económica: Una Visión de Conjunto", en Matrimonio civil y divorcio, Análisis critico y criterios para la aplicación de la Ley $N^{o}$ 19.947, de 2004, Cuadernos de Extensión Jurídica No11, Universidad de los Andes, Facultad de Derecho, p. 105.

- Etcheberry, Alfredo (2005). Derecho Penal. Parte General. Santiago: Editorial Jurídica de Chile, Reimpresión de la tercera edición, 2 volúmenes.

- Fueyo Laneri, Fernando (1991). Cumplimiento o incumplimiento de las obligaciones. Santiago: Editorial Jurídica de Chile

- Herane Vives, Francisco (2006). "Reparación por incumplimiento de los deberes matrimoniales", en Estudios de Derecho Civil II. Santiago: LexisNexis, , pp.181-193.

- Hernández Paulsen, Gabriel (2008). Responsabilidad civil por daños ocasionados en las relaciones de familia, en Colegio de Abogados de Chile, Ciclo de charlas los martes al colegio (charla dictada martes 4 de noviembre de 2008), Separata publicada por Revista del Abogado, 34 pp.

- Larroucau García, Matilde (2010). "De la naturaleza y características del Derecho de Familia y del adulterio como fuente generadora de responsabilidad civil", en Revista Chilena de Derecho de Familia (2) 2010. Santiago: Legalpublishing, pp. 199-206. 
- López Díaz, Carlos (2006). Compensación económica en la nulidad y el divorcio. Santiago: Librotecnia.

- Medina, Graciela (2008). Daños en el Derecho de Familia, Segunda edición actualizada. Santa Fe: Rubilzal Culzoni, 688 pp.

- Méndez Costa, María Josefa (2000). "Separación personal, divorcio y responsabilidad civil. Sus fundamentos" en Alterini et al. (2000) Derecho de Daños. Primera Parte. Buenos Aires: Ediciones La Rocca, pp. 637-664.

- Novales Alquézar, Aránzazu (2008). "Responsabilidades especiales. ¿Debería haber en el Derecho matrimonial mecanismos reparatorios?”, en Regimenes especiales de responsabilidad civil, Cuadernos de Análisis Jurídicos. Colección Derecho Privado IV. Santiago, Ediciones Universidad Diego Portales, Escuela de Derecho, pp. 119-150.

- Novellino, Norberto J. (2000). "La causal de adulterio y los dańos producidos al cónyuge inocente" (2000). pp. 337-378, en Derecho de daños. Daños en el Derecho de Familia. Cuarta Parte (A). Buenos Aires: Ediciones La Rocca, 687 pp.

- Novellino, Norberto J. (2000). "Acerca de la procedencia o no de la indemnización por daños en el Derecho de familia", pp. 35-71; en Derecho de daños. Daños en el Derecho de Familia. Cuarta Parte (A). Buenos Aires: Ediciones La Rocca, 687 pp.

- Pizarro Wilson, Carlos (2006). "Responsabilidad civil por no reconocimiento voluntario del hijo de filiación extramatrimonial", en De Verda y Beamonte, José Ramón, Daños en el Derecho de Familia, Revista Aranzadi de Derecho Patrimonial, Edición Monográfica. Madrid: Thompson-Aranzadi, pp. 101-116.

- Pizarro Wilson, Carlos y Vidal Olivares, Álvaro (2010), La compensación económica por divorcio o nulidad matrimonial, Santiago: Legalpublishing.

- Rodríguez Grez, Pablo (2009). Responsabilidad extracontractual. Santiago: Editorial Jurídica de Chile, Reimpresión de la primera edición, 505 pp.

- Rodríguez Guitián, Alma María (2009). Responsabilidad Civil en el Derecho de Familia: Especial referencia al ámbito de las relaciones paterno-filiales. Pamplona: Aranzadi.

- Romero Coloma, Aurelia María (2008). La indemnización entre cónyuges, ex cónyuges y parejas de hecho. Valencia: Tirant lo Banch, pp. 89-100.

- Romero Seguel, Alejandro (2005). "El contenido del derecho de defensa frente a una acción de divorcio", en Assimakópulos Figueroa, A. y Corral Talciani, H., Matrimonio civil y divorcio. Análisis crítico y criterios para la aplicación de la Ley 19.947, de 2004, 
Cuadernos de extensión jurídica (Universidad de los Andes) $\mathrm{N}^{\circ} 11$, pp. 163-180.

- Santibáñez Torres, María Elena y Vargas Pinto, Tatiana (2011). "Reflexiones en torno a las modificaciones para sancionar el femicidio y otras reformas relacionadas (Ley N ${ }^{\circ}$ 20.480)". Revista Chilena de Derecho, Vol. $34 \mathrm{~N}^{\circ}$ 1, pp. 193-207.

- Sambrizzi, Eduardo A. (2001). Daños en el Derecho de Familia. Buenos Aires: La Ley, p. 145.

- Somarriva Undurraga, Manuel (1963). Derecho de familia. Santiago: Ediar Editores Limitada, v. I, n 120.

- Tapia Suárez, Orlando (2006). De la responsabilidad civil en general y de la responsabilidad delictual entre contratantes. Santiago: LexisNexis, $3^{\text {a }}$ edición, 654 pp.

- Vargas Aravena, David (2009). Daños civiles en el matrimonio. Madrid: La Ley - Wolters Kluwer, 428 pp.

- Venegas Ortiz, Pablo Omar y Venegas Alfaro, Andrés Alfonso (2007). La compensación económica en la nueva Ley de Matrimonio Civil. Santiago: Editorial Jurídica de Chile, p.19.

- Vidal Taquini, Carlos H. (1991). Matrimonio Civil, Ley 23.515, Buenos Aires, p. 516. 